\title{
Scaling-up community self-reporting rate for COVID-19: Implication for assessing the perceived stigmatization of COVID-19 survivors among residents of Agege local government, Lagos, Nigeria
}

Olaniyan Akintunde Babatunde ( $\square$ tundebabson23@gmail.com )

Oriire Local Government Health Authority

Owoicho Samuel Amifofun

Nigeria Field Epidemiology and Laboratory Training Programme, Asokoro, Abuja, Nigeria

Sunday Thomas Sola

Nigeria Field Epidemiology and Laboratory Training Programme, Asokoro, Abuja, Nigeria

Abayomi Akande

Department of Community Medicine, University College Hospital, University of Ibadan, Oyo State, Nigeria

Mathias Besong

Nigeria Field Epidemiology and Laboratory Training Programme, Asokoro, Abuja, Nigeria

Baqiah Morenike Yesufu

Isolo Local Council Development Area

Ibukun Mary Akanbi

Department of Community Medicine, Ladoke Akintola University Teaching Hospital, Ogbomoso, Oyo State, Nigeria

Magbagbeola David Dairo

Department of Epidemiology and Medical Statistics, Faculty of Public Health, College of Medicine, University of Ibadan, Oyo State, Nigerai

Research note

Keywords: Stigmatization, COVID-19, survivors, self-reporting, Nigeria

Posted Date: December 7th, 2020

DOI: https://doi.org/10.21203/rs.3.rs-43559/v3

License: (c) (i) This work is licensed under a Creative Commons Attribution 4.0 International License. Read Full License 


\section{Abstract}

Objective: Coronavirus disease 2019 (COVID-19) is an emerging public health problem with over forty-four million confirmed infections globally. Previous studies showed that stigma impedes response activities. Therefore, this study was conducted to assess the perceived stigmatization of COVID-19 survivors among residents of Agege local government, Lagos State, Nigeria. We conducted a cross-sectional survey among 333 consenting residents recruited from Agege local government using a multi-stage sampling technique. An interviewer-administered questionnaire was used to collect data on perceived stigmatization. Bivariate and multivariate analyses were done using Chi-square and logistic regression respectively.

Results: The mean age of the respondents was $35.7 \pm 13.6$ years. The proportion of respondents with poor knowledge was $50.5 \%$ and awareness for COVID-19 was $95.2 \%$. Television and radio were the two major sources of awareness for COVID-19. A higher likelihood of perceived stigmatization was found among those aged $25-49$ years $(\mathrm{aOR}=3.1,95 \% \mathrm{Cl}=1.4-6.7), \geq 50$ years $(\mathrm{aOR}=2.1,95 \% \mathrm{Cl}=1.1-3.9)$ and married respondents $(\mathrm{aOR}=1.8,95 \% \mathrm{Cl}=1.1-2.9)$. To reduce the effect of stigmatization, we recommend a holistic response plan designed with basic facts about COVID-19 using programmes targeting married respondents as well as the adults.

\section{Introduction}

Many infectious diseases are associated with stigma and this has been found to impede the response activities in the control of the outbreak of such diseases. These diseases include Tuberculosis, Human Immunodeficiency Virus (HIV) and leprosy [1-3]. Also, there is a stigma attributed to Coronavirus disease-2019 (COVID-19) which was first discovered in Wuhan, China in December 2019 [4].

Stigma comes in multiple forms such as perceived, internalized, or experienced (discrimination). During the epidemics, people can be discriminated against because of their perceived association with the individuals thought to have come in contact with the virus. Thus, people with such diseases may avoid seeking health care, making it much harder to control the disease.

In Nigeria, after the report of the first case of COVID-19, there was a surge in the number of positive cases, with disturbing evidence of community transmission. For example, the number of cases recorded on the 16th April 2020, 16th May 2020 and 16th June 2020 were 442, 5,621 and 17, 148 respectively [5]. The Nigeria Center for Disease Control (NCDC) reported that this surge was aided by social stigma against people perceived to have contracted the virus [6-8].

Surprisingly, inspite of the effects of stigmatization on the community self-reporting rate $[6,8,9]$, a lot efforts have been geared towards the cure for COVID-19 among other non-pharmacologic preventive measures without corresponding measures to dissipate stigmatization in the community. Hence, this study was designed to assess the perceived stigmatization of COVD-19 survivors among residents of Lagos State.

\section{Methods}

\section{Study location}

The study was carried out in llobu community, Oko-Oba, Agege local government area (LGA) of Lagos State. Agege LGA has a projected 2019 population of 692,686 using a growth rate of $3.4 \%$ and 2006 population figure as the baseline ${ }^{\text {[10] }}$. The LGA is majorly populated by Yoruba ethnic group. Inhabitants were mostly artisans

\section{Study design and population}

This was a descriptive cross-sectional survey carried out in Oko-Oba area of Agege local government area (LGA) of Lagos State between May and June 2020. The study population included all consenting males and females of 18 years and above who were resident in llobu community in Oko-Oba at the time of the study.

\section{Sample size and sampling technique}

A prevalence of $63.0 \%{ }^{[11]}$ of a similar study was used with the margin of error set at $5 \%$. Factoring non-response rate of $10 \%$, a minimum sample size of 394 was arrived at. A multi-stage sampling technique was used. Stage one: Oko-Oba was selected from the list of the catchment areas in Agege LGA using ballot technique. Stage two: llobu community was selected from the list of communities in Oko-Oba area using ballot technique. Stage three: A systematic sampling technique was used to select the eligible respondents from the list of the households retrieved from the office of the National Programme on Immunization (NPI) in Agege LGA. The first household was selected by simple random sampling through a ballot and all the eligible respondents interviewed. Subsequently, every 4th house was selected until the desired sample size was met.

\section{Research instrument and data collection methods}


The COVID-19 related stigma was measured by an interviewer-administered questionnaire adapted from the previous studies [12-14]. We engaged eleven of the 20 people trained by WHO for active case search (ACS). They were trained for two days, 2 hours daily by the principal investigator on data capturing tools and the techniques for questionnaire administration.

\section{Measurement of main outcome variables}

Knowledge score was assessed using questions adapted from the previous studies $[15,16]$. Each correct response was scored one point while each wrong response was scored zero. The total obtainable score was 7 which agrees with a Chinese study [17]. Perceived stigmatization was assessed using an adapted HIV-Stigma Index [12]. The stigmatization scale used consists of negative attitude, perceived discrimination and equity (Additional file 3:S3). The mean stigmatization score was 68.8. The respondents who scored up to or above the mean were categorized as those with perceived stigmatization. The Cronbach's alpha coefficient of the perceived stigmatization questionnaire was 0.84 in our sample, indicating acceptable internal consistency.

\section{Data Analysis}

Data were analyzed using IBM SPSS version 25. Categorical variables were reported as frequencies and proportions/percentages. Associations between the stigmatization and other categorical variables were assessed using Chi-square. Logistic regression was used identify the predictors of the perceived stigmatization of COVID-19 survivors. The level of statistical significance was set at $p<0.05$.

\section{Results}

\section{Socio-demographic characteristics of the respondents}

The mean age of the respondents was $35.7 \pm 13.6$. The proportion of respondents in the $25-49$ years age category was $59.8 \%$ with a higher proportion (56.8\%) of male respondents. Married respondents were 51.7\%, 56.0\% were Christians and 53\% belonged to the Yoruba ethnic group. Nearly half (48.6\%) had secondary education, $37.3 \%$ engaged in trading/farming and $36.5 \%$ had a monthly income of <N30, 000.00 (Additional file 1: S1)

\section{Awareness of COVID-19 Outbreak among the respondents}

The proportion of respondents who were aware of the outbreak of COVID-19 in Nigeria was 95.2\%. (Additional file 1: S1)

\section{Sources of information about COVID-19 among the respondents}

Television (43.5\%) and radio (36.9\%) were the two main sources of information about COVID-19. Others include internet (29.7\%), family/friend (14.8\%) and newspapers (3.2\%). (Additional file 1: S1)

\section{Knowledge of COVID-19 among the respondents}

There was marginally higher proportion of the respondents with poor knowledge (50.5\%) than those with good knowledge. (Additional file 1 : S1)

\section{Mode of Transmission of COVID-19 among the respondents}

Cough and sneezing were commonest (56.0\%) mode of transmission followed by contacts (34.0\%), rat-bite (4\%), I don't know (4\%) and mosquito bite (2.0\%). (Additional file 1: S1)

\section{Perceived stigmatization of COVID-19 survivors among the respondents}

The proportion of respondents whose behaviour indicated perceived stigmatization of COVID-19 survivors was 47.7\%. (Fig. 1) (Additional file 3: S3)

Fig. 1 Perceived stigmatization among residents of Ilobu community, Agege LGA, Lagos State, 2020

Association between the socio-demographic characteristics and perceived stigmatization of COVID-19 survivors among the respondents

A higher proportion (59.2\%) of perceived stigmatization was reported among the respondents in the 25-45 years age category ( $p<0.001)$. The proportion of respondents with the perceived stigmatization of COVID-19 survivors was significantly higher among the married respondents ( $p<$ 0.001). Trading/farming appeared to be the occupation with a significantly higher proportion (42.8\%) of respondents with perceived stigmatization of COVID-19 survivors $(p=0.003)$ (Table 1)

Table 1: Association between demographic characteristics and perceived stigmatization of COVID-19 survivors among the respondents, 2020 


\begin{tabular}{|c|c|c|c|}
\hline \multirow[b]{2}{*}{ Variables } & \multicolumn{2}{|c|}{ Perceived Stigmatization (\%) } & \multirow[b]{2}{*}{$P$ value } \\
\hline & Yes & $\overline{\text { No }}$ & \\
\hline \multicolumn{4}{|l|}{ Age (in years) } \\
\hline$<25$ & $25(15.7)$ & $51(29.3)$ & $*<0.001$ \\
\hline $25-49$ & $96(60.4)$ & $103(59.2)$ & \\
\hline$\geq 50$ & $38(23.9)$ & $20(11.5)$ & \\
\hline \multicolumn{4}{|l|}{ Sex } \\
\hline Male & $84(52.8)$ & $105(60.3)$ & 0.167 \\
\hline Female & $75(42.7)$ & $69(39.7)$ & \\
\hline \multicolumn{4}{|l|}{ Marital status } \\
\hline Single & $33(20.8)$ & $79(45.4)$ & $* *<0.001$ \\
\hline Married & $97(61.0)$ & $75(43.1)$ & \\
\hline Separated & $19(11.9)$ & $6(3.4)$ & \\
\hline Divorced & $6(3.8)$ & $9(5.2)$ & \\
\hline Widowed/Widower & $4(2.5)$ & $5(2.9)$ & \\
\hline \multicolumn{4}{|l|}{ Religion } \\
\hline Christianity & $81(50.9)$ & $107(61.5)$ & 0.282 \\
\hline Islam & $62(39.0)$ & $54(31.0)$ & \\
\hline Traditionalist & $15(9.4)$ & $12(6.9)$ & \\
\hline Others & $1(0.6)$ & $1(0.6)$ & \\
\hline \multicolumn{4}{|l|}{ Tribe } \\
\hline Yoruba & $79(49.7)$ & $98(56.3)$ & 0.188 \\
\hline Hausa/Fulani & $19(11.9)$ & $20(11.5)$ & \\
\hline Igbo & $47(29.6)$ & $36(20.7)$ & \\
\hline Others & $14(8.8)$ & $20(11.5)$ & \\
\hline \multicolumn{4}{|l|}{ Highest Education } \\
\hline Informal & $3(1.9)$ & $10(5.7)$ & 0.192 \\
\hline Primary & $19(11.9)$ & $27(15.5)$ & \\
\hline Secondary & $83(52.2)$ & $79(45.4)$ & \\
\hline Tertiary & $54(23.8)$ & $72(43.6)$ & \\
\hline \multicolumn{4}{|l|}{ Occupation } \\
\hline Unemployed & $27(17.0)$ & $44(25.3)$ & $* 0.003$ \\
\hline Trading/Farming & $61(38.4)$ & $48(27.6)$ & \\
\hline Government employee & $6(3.8)$ & $10(5.7)$ & \\
\hline Private employee & $53(33.3)$ & $42(24.1)$ & \\
\hline Others & $5(3.1)$ & $22(12.6)$ & \\
\hline \multicolumn{4}{|c|}{ Average Monthly Income $(n=181)$} \\
\hline$<30,000$ & $28(32.9$ & $38(39.6)$ & 0.354 \\
\hline$\geq 30,000$ & $57(67.1)$ & $58(60.4)$ & \\
\hline
\end{tabular}

* Significant

** Likelihood Ratio

Association between awareness, source of information, knowledge and the perceived stigmatization of COVID-19 survivors among the respondents

There was no significant association between awareness, source of information and the perceived stigmatization of COVID-19 survivors. (Additional file 1: S1)

\section{Predictors of stigmatization of COVID-19 survivors among the respondents}

The respondents in the age categories $25-49$ and $\geq 50$ years were 3 and 2 times respectively more likely to stigmatize COVID-19 survivors compared with the respondents of less than 25 years of age $[(\mathrm{aOR}=3.1,95 \% \mathrm{Cl}=1.4-6.7)$ and $(\mathrm{aOR}=2.1,95 \% \mathrm{Cl}=1.1-3.9)]$. The married respondents had about 2 times higher likelihood of stigmatizing COVID-19 survivors compared with other levels of marital statuses (Single/Separated/Divorced/Widowed/Widower). (aOR=1.8, 95\% Cl = 1.1 - 2.9) (Table 2)

Table 2: Predictors of perceived stigmatization of COVID-19 survivors among residents of Agege LGA, Lagos State, 2020 


\begin{tabular}{|c|c|c|c|c|c|}
\hline \multirow{2}{*}{ Variables } & \multirow[b]{2}{*}{$\begin{array}{c}\text { B } \\
\text { Coefficient }\end{array}$} & \multirow[b]{2}{*}{$\begin{array}{l}\text { Odd } \\
\text { Ratio }\end{array}$} & \multicolumn{2}{|c|}{$95 \%$ Confidence Interval } & \multirow{2}{*}{ p-Value } \\
\hline & & & Lower & Upper & \\
\hline \multicolumn{6}{|l|}{ Age (in years) } \\
\hline $25-49$ & 1.145 & 3.143 & 1.482 & 6.665 & $* 0.003$ \\
\hline$\geq 50$ & 0.747 & 2.111 & 1.140 & 3.910 & $* 0.018$ \\
\hline Marital status & & & & & \\
\hline $\begin{array}{l}\text { Single/Separated/Divorce/Widowed/Widower } \\
\text { Married }\end{array}$ & $\begin{array}{c}1 \\
0.603\end{array}$ & 1.827 & 1.153 & 2.896 & $* 0.010$ \\
\hline \multicolumn{6}{|l|}{ Occupation } \\
\hline $\begin{array}{l}\text { Unemployed } \\
\text { Employed }\end{array}$ & 1 & 1276 & $060 ?$ & ר? & 0106 \\
\hline Employed & 0.203 & 1.226 & 0.682 & 2.203 & 0.496 \\
\hline
\end{tabular}

* Significant

\section{Discussion}

The overall awareness of COVID-19 outbreaks among the respondents was $95.2 \%$ with male predominance and this could be attributed to higher educational attainment by the male respondents. This high prevalence could result from the effectiveness of the strategies deployed to disseminate COVID-19 information by the Government of Nigeria. Mass media, particularly television (43.5\%) and radio (36.9\%) were found as the major sources of information about COVID-19 and this corroborated findings from the previous studies [18-22]. However, it negated the report of Abdelhafiz et al in Egypt where the social media and internet were the major sources of information during this COVID-19 outbreak [13]. In view of this, the mass media should be intensively used to further propagate awareness, most especially on non-pharmacologic prevention.

The study revealed poor knowledge of COVID-19 among the study subjects and could result from the low tertiary educational status and 'unstable' epidemiologic pattern of the virus. This agreed with what was documented in some Nigerian and Bangladesh studies [23-26] but opposed to what was reported in Egyptian and Chinese studies where a higher prevalence of good knowledge of COVID-19 was documented $[17,19]$. The higher prevalence recorded in these two studies could be due to the recruitment of seemingly educated online study populations.

On the mode of transmission of COVID-19, the majority of the respondents reported cough, sneezing and contacts as the major routes of transmission. This testifies to the dissemination of correct information about the way the virus spreads. However, efforts should be geared towards scaling-up information dissemination so as to catch-up with the handful proportion of those with incorrect knowledge of the mode of transmission of the virus.

The prevalence of perceived stigmatization was $47.7 \%$ and many studies on similar infectious diseases such as Severe Acute Respiratory Syndrome (SARS), tuberculosis and Ebola corroborated our result by demonstrating the negative effects of stigmatization on the preventive and control efforts $[1,22,27]$. Stigma against the survivors poses significant barriers and makes access to treatment a herculean task. Incidentally, this may cause unnecessary delay in seeking care and this could aggravate the suffering of the survivors [28-30].

The respondents in the age of 25 years and above were potentially more likely to stigmatize against COVID-19 survivors compared with those who belonged to the age group of less than 25 years. This was not surprising because youths are known for their explorations and knowledgeseeking behaviours compared with the adults. Their penchants for knowledge could have afforded them the opportunity of understanding the epidemiology of COVID-19, hence, their low predisposition to perceived stigmatization in this study. This is consistent with the reports of Des Jarlais et al. and Usifoh et al. in the U.S.A and Nigeria respectively [31,32].

Married respondents were more likely to stigmatize the survivors of COVID-19 compared with other forms of marital statuses because they are more involved in cultural issues and often listen to advice from their families where stigma was found to be emanating from [33,34]. In order to stem this ugly tide, efforts should be geared towards community engagement and raising public awareness on the myths and facts relating to COVID-19 pandemic.

\section{Conclusion}

Adults and married women displayed a high level of perceived stigmatization and this could be attributable to poor knowledge. To scale-up selfreporting for COVID-19, we recommend a holistic emergency response plan, packaged with accurate knowledge targeting married respondents as well as the adults.

\section{Study limitation}


Social desirability bias was envisaged and this was reduced by avoiding the leading questions and use of interval questions. We might not be able to generalize our findings to the whole country. However, the findings of our study could be extrapolated to the Southern part of Nigeria because of the similarities in the socio-economic and cultural characteristics. This is the first psychosocial survey to assess stigmatization in the control of community transmission of COVID-19 in Nigeria.

\section{List Of Abbreviations}

$\begin{array}{ll}\text { LGAs } & \text { Local Government Areas } \\ \text { ACS } & \text { Active Case Search } \\ \text { WHO } & \text { World health Organization } \\ \text { NCDC } & \text { Nigeria Centre for Disease Control } \\ \text { COVID-19 } & \text { Corona Virus Disease, 2019 } \\ \text { SARS } & \text { Severe Acute Respiratory Syndrome } \\ \text { EVD } & \text { Ebola Virus Disease } \\ \text { HIV } & \text { Human Immunodeficiency Virus }\end{array}$

\section{Declarations}

\section{Ethical approval and consent to participate}

We obtained the approval for the study from the Ethical Review Committee, Oyo State Ministry of Health (No: AD13/479/1998). We informed all the respondents about the study protocols and adherence to confidentiality. Written informed consent was obtained from all the participants

\section{Consent for Publication}

Not applicable

\section{Availability of data and materials}

The respondents used to generate this data have not been reported in any other submission by the authors or anyone else. However, upon request, we can offer on-site access to external researchers to the data analyzed at the Oriire Local Government Health Authority, Ikoyi-Ile, Oyo State, Nigeria. To do so, Dr. Olaniyan Akintunde Babatunde should be communicated.

\section{Competing interests}

The authors declared no competing interests.

\section{Funding}

No financial support was received for this research

\section{Authors' information}

\section{Affiliations}

Oyo State Primary Health Care Board, State Secretariat, Agodi, Ibadan, Oyo State, Nigeria

Olaniyan Akintunde Babatunde

Oriire Local Government Health Authority, Ikoyi-Ile, Oyo State, Nigeria

Olaniyan Akintunde Babatunde

Nigeria Field Epidemiology and Laboratory Training Programme, Asokoro, Abuja, Nigeria

Owoicho Samuel Amifofun, Sunday Thomas Sola, Mathias Besong 
Department of Community Medicine, University College Hospital, University of Ibadan, Oyo State, Nigeria

Abayomi Akande

Isolo Local Council Development Area, Isolo, Lagos State, Nigeria

Baqiah Morenike Yesufu

Department of Community Medicine, Ladoke Akintola University of Technology Teaching Hospital, Ogbomoso, Oyo State, Nigeria

Ibukun Mary Akanbi

Department of Epidemiology and Medical Statistics, Faculty of Public Health, College of Medicine, University of Ibadan, Oyo State, Nigeria

Magbagbeola David Dairo

\section{Contributions}

OAB conceptualized the study, OSA, STS, AAA, MB, BMY, IMA and MDD contributed to the design, OAB drafted the initial manuscript, OAB, OSA, STS, AAA MB, BMY, IMA and MDD contributed to the analysis, interpretation of the results and made substantial revision to the initial draft. All authors read and approved the final version of the manuscript.

\section{Corresponding author}

Correspondence to Olaniyan Akintunde Babatunde

\section{Acknowledgements}

The authors appreciate the Medical Officer of Health, Agege Local Government Health Authority and the members of the active case search team used for the data collection. We equally appreciate the residents of llobu community, Oko-Oba, Agege that participated in the study for their cooperation.

\section{References}

1. Faccini M, Cantoni S, Ciconali G, et al. Tuberculosis-related stigma leading to an incomplete contact investigation in a low incidence country. Epidemiol Infect. 2015;143:2841-2848.

2. Parker R, Aggleton P. HIV and AIDS-related stigma and discrimination: a conceptual framework and implications for action. Soc Sci Med. 2003; 57: 13-24.

3. Cross H. Interventions to address the stigma associated with leprosy: a perspective on the issues. Psychol Health Med 2006; $11: 367-73$.

4. World Health Organization (WHO) https://www.who.int/emergencies/diseases/novel-coronavirus-2019/question-and-answers-hub/q-adetail/q-a-coronaviruses [ assessed 19th May, 2020].

5. Nigeria Center for Disease and Control (NCDC). No Title. [Internet]. COVID-19 Nigeria. https://covid19.ncdc.gov.ng/[accessed 21 June, 2020].

6. Nigeria Center for Disease Control (NCDC). No Title (Internet]. Stigma against COVID-19 patients affecting our efforts. Available from https://www.premiumtimesng.com/news/top-news/388339-stigma-against-covid-19-patients-affecting-our-efforts-ncdc.html [ac.

7. Social Stigma associated with COVID-19. https://www.unicef.org/media/65931/file/Social\%20stigma\%20associated\%20with\%20the\%20coronavirus\%20disease\%202019\%20(COVID19).pdf [assessed 19th May, 2020].

8. Oaten M, Stevenson RJ, Case TI. Disease avoidance as a functional basis for stigmatization. Philos Trans R Soc Lond B Biol Sci. 2011; 366(1583):3433-3452.

9. World Health Organization and the Governments of Guinea, Liberia, and Sierra Leone. [Internet]. Ebola Virus Disease Outbreak Response Plan in West Africa; . Available online: http://www. who.int/csr/disease/ebola/evd-outbreak-response-plan-westafrica- 201.

10. Federal Republic of Nigeria Official Gazette. Legal Notice on Publication of 2006 Census Final Results. 2009;96(2):B1-42.

11. Kelly JD, Weiser SD, Barthalomew W, Cooper JB, Sneller MC, Michael C, Clara D, Steward WT, Cavan R, Kumblytee J and Fallah MP. Ebola virus disease-related stigma among survivors declined in Liberia over an 18- month, post-outbreak period: An observation. 2019;13(2):1-12.

12. National AIDS Commission. The People Living with HIV Stigma Index: Liberia PLHIV Stigma Index Report. November 2013. Available at: http://www.stigmaindex.org/sites/default/files/reports/Liberia\% 20\%20People\%20Living\%20with\%20HIV\%20Stigma\%20Index\%20Final\%2.

13. Abdelhafiz AS, Mohammed Z, Ibrahim ME, Ziady HH, Alorabi M, Ayyad M, Sultan EA. Knowledge, Perceptions, and Attitude of Egyptians Towards the Novel Coronavirus Disease (COVID-19). J Community Health [Internet] 2020;Available from: https://doi.org/10.1007/s10900- 
020-00827-7

14. Bao-Liang Z, Wei L, Hai-Mei L, Qian-Qian Z, Xiao-Ge L, Wen-Tian L and Yi L. Knowledge, attitudes, and practices towards COVID-19 among Chinese residents during the rapid rise period of the COVID-19 outbreak: a quick online cross-sectional survey. Inter. 2020;16(10):1745-52.

15. China. Guideline for the diagnosis and treatment of 2019 novel coronavirus (2019-nCoV) infected pneumonia (The Third Trial Version). 2020. http://www.nhc.gov.cn/yzygj/s7653p/202001/f492c9153ea9437bb587ce2ffc bee1fa.shtml (access March 23, 2020.

16. National Health Commission of the People's Republic of China. A protocol for community prevention and control of the 2019 novel coronavirus (2019-nCoV) infected pneumonia (trial version). 2020. http://www.nhc.gov.cn/jkj/s3577/202001/dd1e502534004a8d88b6a1.

17. Zhong BL, Luo W, Li HM, et al. Knowledge, attitudes, and practices towards COVID-19 among Chinese residents during the rapid rise period of the COVID-19 outbreak: A quick online cross-sectional survey. International Journal of Biological Sciences. 2020;16.

18. Olapegba OP, Olusola Ayandele O, Kolawole SO, Oguntayo R, Gandi JC, Dangiwa AL, Ottu IFA, lorfa SK doi: https://doi.org/10.1101/2020.04.11.20061408 Preprint[accessed 15th June, 2020].

19. Abdelhafiz AS, Mohammed Z, Ibrahim ME, Ziady HH, Alorabi M, Ayyad M, Sultan EA. Knowledge, Perceptions, and Attitude of Egyptians Towards the Novel Coronavirus Disease (COVID-19). J Community Health. 2020; Apr 21:1-10. doi: 10.1007/s10900-020-00827-7 [Ep.

20. Lau JTF, Yang X, Tsui H, JKim JH. Monitoring community responses to the SARS epidemic in Hong Kong: from day 10 to day 62 . J Epidemiol Commun Health. 2003; 57(11):864-70. doi: 10.1136/jech.57.11.864. 8 864-70.

21. Gidado S, Oladimeji AM, Roberts AA, Nguku P, Nwangwu IG, Waziri NE, Shuaib F, et al. Public Knowledge, Perception and Source of Information on Ebola Virus Disease Lagos, Nigeria; September, 2014. PLOS Currents Outbreaks. 2015 Apr 8 . Edition 1.

22. Chinenye, Mgbe. Knowledge, Attitudes and Practices (Kap) of Ebola Virus Disease: Enugu State Metropolis Survey in Nigeria. South American Journal of Public Health. 2013;4(2):1-10.

23. Odigie EA, Ighedosa SU, Osaghae VG, Usifoh SF, Asemota DO, Aighewi IT, et al. Risk perception of Lassa fever and rodent control practices in a university campus in South-South zone of Nigeria. Nigerian Soc Exp Biol J. 2017;17:14-22.

24. Usifoh SF, Ighedosa SU, Aighewi IT, Asemota OD, Odigie EA, Faboya T. Impact of Lassa fever on the practice and consumption of stored food by University of Benin community, in Benin City, Nigeria. J Community Med Prim Health Care. 2018;30: 66-76.

25. Ighedosa SU, Asemota O, Aighewi IT, Odigie EA, Usifoh SF, Omorogbe CE, et al. Knowledge, attitude and prevention practices of Lassa fever by staff of University of Benin, Benin City. Nigerian Soc Exp Biol J. 2017;17:82-90.

26. Abdul Wadood, ASMA Mamun, Abdur Rafi, kamrul Islam, Suhaili Mohd, Lai Lee Lee, Golam Hossain. Knowledge, attitude, practice and perception regarding COVID-19 among students in Bangladesh: Survey in Rajshahi University. BMJ. 2020. [Preprint]h.

27. Brug J, Aro AR, Oenema A, de Zwart O, Richardus JH, Bishop GD. SARS risk perception, knowledge, precautions, and information sources, the Netherlands. Emerg. Infect. Dis. 2004;10 (8):1486-1489.

28. Cashman KA, Smith MA, Twenhafel NA, Larson RA, Jones KF, Allen RD, et al. Evaluation of Lassa antiviral compound ST-193 in a guinea pig model. Antiviral Res. 2011;90:70-9.

29. Cunningham SD, Kerrigan DL, Jennings JM, Ellen JM. Relationships between perceived STD-related stigma, STD-related shame and STD screening among a household sample of adolescents. Perspect Sex Reprod Health. 2009;41:225-30.

30. Sayles JN, Wong MD, Kinsler JJ, Martins D, Cunningham WE. The association of stigma with self-reported access to medical care and antiretroviral therapy adherence in persons living with HIV/AIDS. J Gen Intern Med. 2009;24:1101-8.

31. Des Jarlais DC, Galea S, Tracy M, Tross S, Vlahov D. Stigmatization of newly emerging infectious diseases: AIDS and SARS. Am J Public Health. 2006;96:561-7.

32. Usifoh SF, Odigie AE, Ighedosa SU, Uwagie-Ero EA, Aighewi IT. Lassa Fever-associated Stigmatization among Staff and Students of the University of Benin, Nigeria. Journal of Epidemiology and Global Health. 2019; 9(2):107-115.

33. WHO. [Internet]. Social stigma threatens COVID-19 response but patients heal faster with everyone's support.

https://www.afro.who.int/news/social-stigma-threatens-covid-19-response-patients-heal-faster-everyones-support[accessed 19 June, 2020].

34. Hewlett BS, Amola RP. Cultural contexts of Ebola in northern Uganda. Emerg Infect Dis. 2003;9:1242.

\section{Figures}


Perceived stigmatization among residents of Agege LGA, Lagos State, 2020

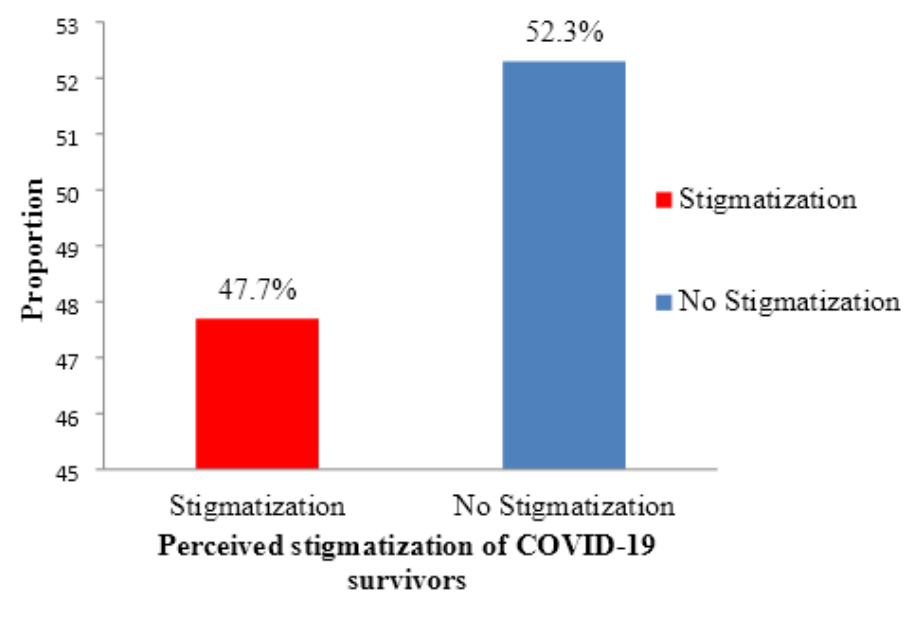

\section{Figure 1}

Perceived stigmatization among residents of Ilobu community, Agege LGA, Lagos State, 2020

\section{Supplementary Files}

This is a list of supplementary files associated with this preprint. Click to download.

- Additionalfile1.pdf

- Additionalfile2STIGMATIZATION.pdf 